\title{
The poverty of numbers: reflections on the legitimacy of global development indicators
}

\author{
Morag Goodwin*
}

\begin{abstract}
It is no surprise that development institutions and actors have taken to indicators with such enthusiasm. Where indicators are both a form of knowledge production and simultaneously a technology of governance, they are a form of soft powers that allow such actors to set the standards for what it is to be developed in the twenty-first century. Such measures of civilisation have been dominant throughout a history of Global North-South encounters: measurement was central to the many forms of colonial control, from map-making to craniometry, to the global 'discovery' of poverty in the I940s. This paper seeks to place development indicators in this colonial context by focusing on the issue of comparability or the global claim that underpins global development indicators.
\end{abstract}

\section{Introduction}

It is no surprise that development institutions and actors have taken to indicators with such enthusiasm. Where indicators are both a form of knowledge production and simultaneously a technology of governance, they are a form of soft power that allows such actors to set the standards for what it is to be developed in the twenty-first century (Merry et al., 20I5). Such measures of civilisation have been dominant throughout a history of Global North-South encounters: measurement was central to the many forms of colonial control, from map-making to craniometry, to the global 'discovery' of poverty in the I940s (Bassett, I994; Escobar, 1995). Like these historical measurements, contemporary global development indicators, as with all measurements, make a claim to an objective truth - a claim of representation of an independently existing fact (Michell, 2005). This claim has been the basis of the two main critiques of social indicators: the poor numbers critique or what we might call the accuracy critique, which contests the accuracy of the data upon which indicators are based (also Jerven, 2013); and the complexity critique, which challenges the ability of numbers to capture the complexity of that which indicators seek to measure, whether an entrepreneurial environment or something seemingly more straightforward such as the number of malaria-related deaths in a given year and location (e.g. Davis and Kruse, 2007; Gerrets, 2015). This paper seeks to develop a different critique. In place of challenging the conceptualisation of a given social indicator or social indicators in general, the focus here is on the issue of comparability or the global claim that underpins global development indicators. ${ }^{\mathrm{I}}$

* Chair of Global Law and Development, Tilburg Law School; E-mail: m.e.a.goodwin@uvt.nl. My thanks to the participants in the workshop 'Global Social Indicators: Constructing Transnational Legitimacy', King's College London, I4-I5 March 2016, for their comments on an earlier version of this paper and to David Nelken and Mathias Siems for the invitation to participate. Thanks, too, to the anonymous referees for their helpful comments.

I The arguments that form the basis of this critique are not new; what is hopefully different is the explicit targeting of the claim to global validity. It is also perhaps helpful to note that global development indicators are understood here to be a subset of global social indicators; the critique developed may be applicable to global social indicators more broadly but that would be an argument for another paper. 
The aim of this paper is not, then, to contribute a new case-study to the on-going work on indicators as global governance project. The work of Davis, Merry, Kingsbury and others has very effectively demonstrated how indicators function as a technology of governance, dissecting carefully the stages of knowledge production - how indicators are conceptualised and data are collected - and the effects that indicators produce, including resistance and co-opting strategies. This paper instead draws upon this work to develop a more general critique of development indicators. In order to do this, it is necessary to be clear about my target: I am not taking aim at data or data collection on development in general, albeit that I recognise the potency of the accuracy and complexity critiques. Despite the deep flaws in seeking to measure social phenomenon, we nonetheless need some way of talking about the success or failure of development efforts and, while success (or failure) cannot be measured in numbers alone, namely in wage increases or percentages of children in school, numbers can help us make sense of a complex picture. Whether a community-based project has succeeded in enhancing the lives of community members might be partly measured by a higher level of household disposable income or by levels of female participation; more crucially, the success or failure of a project should be measured by how its participants feel about whether their lives have improved or not. This latter information is hard to gather, even harder to analyse and disseminate. An understandable way of doing so is to assign numbers to it: for example, we might record a participant's statement that her participation in the project has greatly improved her sense of self-worth, her relations with her neighbours and her children's school attendance with a 5 on a scale of $0-5$, where these criteria are the standards the participant herself has chosen. A reflexive, participatory approach at all levels of assessment when measuring the success or failure of development efforts is essential to understanding development interventions. This information helps us to record and to measure a project's outcomes and this allows us to conduct a cost-benefit analysis, where the benefit can equally be the pleasure drawn from smelling of roses as an increase in income (Alkire, 2002).

This paper, then, is not against efforts to measure development efforts. Clearly, there needs to be some attempt to do so and, when done in a reflexive, participatory manner, the information not only allows us to evaluate a project, but also challenges and recreates the measures themselves. Moreover, there can be good reasons for transposing qualitative data into numbers and of combining quantitative measurements and qualitative data into datasets. Numbers allow easy and quick comprehension and are thus ideal for the studying of information on multiple projects. The attempt to render complex feelings about how well one's life is going into numbers is always problematic and will create inaccuracies of scale and emphasis. The alternative, however, is that we do not measure the success or failure of projects and that we therefore do not deepen our understanding or learn lessons. Although measurement has a place in development studies, I nonetheless wish to challenge the legitimacy of global development indicators.

\section{Global development indicators}

Much work has already been done to analyse the nature and functioning of indicators. Nonetheless, in order to make claims about how global development indicators function and to challenge their legitimacy on a general basis, it is necessary to give, first, some indication as to what I understand global development indicators to be and, second, what claim I think they make - explicitly or implicitly - to legitimacy.

In their 2012 introduction to their first collected study on indicators, Davis, Kingsbury and Merry defined indicators as 'a named collection of rank-ordered data that purports to represent the past or projected performance of different units' (Davis et al., 20I2, p. 6). Put simply, indicators are standards expressed in numerical form. They are simplifications of any and all aspects of human life, depending on what they purport to measure, into benchmarks that are used to evaluate performance. This 
simplification takes place at a number of levels but the result is, in the words of Wendy Espeland, "the systematic removal of the persons, places and trajectories of the people being evaluated by the indicator' (2015, p. 56). It is this simplification that makes indicators so useful, so attractive; but, in isolating a single element or interconnected elements of human life from their context, indicators are necessarily highly abstract and thus reductive.

Indicators are thus not merely numbers that are used to judge all areas of human life, from the most intimate to the public governance of a state. Indicators both produce knowledge in their application and are themselves the product of knowledge (knowledge about what to measure and how); in this, they are - as others have noted - a technology of knowledge production, but also a form of knowledge assumption, of epistemological ring-fencing. Indicators are a technology of communication; they function by communicating these knowledges of creation and production. At the same time, indicators create relationships among the things or people that they purport to measure in the process of ordering them according to a common metric (Espeland, 20I5, p. 59). It is this commensurability that allows for comparison and for ranking.

Indicators are also tools or technologies of governance. The governance functions of indicators are multiple and operate in different ways (see e.g. Merry et al., 2015). Of most relevance here in the context of global development indicators is the way in which the governance power of indicators is based on two distinct effects. The hard, direct effect of development indicators is found in the allocation of resources where indicators are used as bases of development funding decision-making. The easiest example is the Country Policy and Institutional Assessment (CPIA) database of the World Bank, which was created explicitly to play a determining role in deciding which states receive World Bank loans and other types of development funding. ${ }^{2}$ Development indicators, such as the CPIA, also influence the ability of states to raise money on the private market or the flows of FDI to a country. The second type of governance effect concerns the disciplinary power of indicators. This has been alternatively labelled soft or quiet power, although it is no less powerful than the direct impact on funding opportunities and is arguably more so. The disciplinary power of indicators flows both from their prescriptive nature and the comparative relationship they create. This power has both external and internal effects: indicators are used by external parties to judge a thing or people by reference to a certain standard, as well as in relation to other things or people. How we think about how well a country or institution is functioning is influenced by how they measure up against the standard set and in relation to other countries or institutions. Indicators provide a means of measuring success or failure. This can have all kinds of consequences related to the relative status of a state or actor on the international stage. When a state is seen as performing well according to influential indicators, for example, its importance as a regional or global actor will increase, and this is likely to have, inter alia, geopolitical and economic consequences.

Indicators also affect the self-understanding of those being measured and assessed. They have a self-disciplinary power that is both conscious and unconscious. Indicators assign responsibility for monitoring and improving performance to the target (Uribe, 2015) and provide a measure of selfunderstanding of success or failure and one that functions in relation to others. That a country nestles around the bottom of an indicator on transparency or on quality of life affects thus not only how outsiders evaluate a country's performance, but also how they think about themselves. It may affect how the subject of an indicator acts, in conscious response or otherwise to their position in a ranking. ${ }^{3}$ While this can be seen as having a positive function - if it motivates a

2 See 〈http://data.worldbank.org/data-catalog/CPIA〉 (accessed Io October 20I7).

3 Note that a response to positioning in a ranking may not be a negative one of self-doubt or self-reproving, but can also be one of resistance and self-assertion. See Serban (20I5). 
state to improve governance in health care, how could this be a bad thing? - it can also have the function of confirming or reinforcing a sense of inferiority, which in the context of development was put in place in the colonial encounter. Together, the external and internal disciplinary power of global indicators helps to frame and structure relations between states; it is this that makes them such a powerful instrument of global governance.

If indicators in general are technologies of simplification, of communication and of governance, what are global development indicators? How one answers this question depends to a large extent on how one defines development. Development is a classic example of an essentially contested concept (Gallie, I956); that said, the concept of development as it is most commonly used in global discourse concerns deprivation, whether measured by a narrow material measure or by a richer understanding of human well-being. Under this definition of development, we can further categorise development indicators into three types: economic indicators - these numbers concern the size and growth of the national economy, usually measured as GDP or sometimes as GNP; they can be broken down into sectors of the economy or detail investment inflows, for example; second, poverty indicators - while economic indicators are concerned with the comparative wealth of nations, poverty indicators reflect the relative inequality within and across countries; an example is the famous Global Poverty Line of the World Bank, ${ }^{4}$ which is an attempt to set a global standard of extreme poverty valid in all countries based on purchasing power parity (Reddy and Pogge, 2010). Examples that take a more multivaried approach to poverty - those that view poverty as more than simply spending power - include the Human Development Index (HDI) and, more recently, the Individual Deprivation Measure (Pogge and Wisor, 20I6). Indicators that seek to measure individual aspects of well-being, such as health-care indicators, could also be placed in this category. The third type of development indicators are governance indicators. While all development indicators have a governance function, governance indicators are defined by the claim that they directly measure governance, whether by sector or by interest or more broadly. The World Justice Project's Rule of Law Index or Freedom House's Freedom in the World indicator are examples of governance indicators; further examples include the Doing Business Indicator and the Good Governance data of the World Bank. Indicators measuring human rights compliance also belong in this third category, even where they include social and economic rights, as such human rights indicators most commonly measure the ability of a state to fulfil its human rights obligations rather than whether or not an individual actually enjoys, for example, access to water.

If the above delineates a broad scope for development indicators, it remains to define a global development indicator. The epithet 'global' seems to require us to exclude the internal indicators used by individual organisations, such as Oxfam or DFID, to judge the success or failure of development projects, although these indicators are very important in the governance of development. They are included, however, where these internal indicators become a global reference point for development actors. My main criteria for defining a development indicator as global is instead the measurement of comparative state performance in the field of development. Under this definition, the source of the data used in the indicator is not important; for example, whether the indicator makes use of state-produced data or conducts independent data collection; whether it relies on national data (data concerning nationwide performance) or on local data; or whether it is compiled of quantitative data or qualitative data that is then converted into numerals. The producer of the indicator is also irrelevant to the definition. A global development indicator can be the product of public bodies, such as international institutions or government departments, or it can be produced by private actors, such as Transparency International. The stated purpose of the indicator or the way in which indicators work are also not relevant, namely

4 See 〈http://www.worldbank.org/en/topic/poverty/brief/global-poverty-line-faq〉 (Io October 20I7). 
whether the engineers of an indicator or those marketing it understand it to be measuring development. Instead, it is the effect or use to which a given indicator is put under the definition laid out above that matters. Further, the concept of global used here may include regional indicators, such as the African Leaders Malaria Alliance (ALMA) Scorecard, where the evaluation of state performance is set by reference to global standards (Gerrets, 2015).

A global development indicator here is thus a compilation of data that claims to measure and evaluate the relative performance of state actors in the field of development, where development is understood as deprivation. Such a delineation has the virtue of being relatively simple in limiting global development indicators to those that seek to measure and evaluate state performance.

\section{The globality critique}

At the core of indicators, as we noted above, is the claim to measure something by reference to a shared or standard metric. Global social indicators claim to measure an aspect of social life namely people - by reference to a standard metric that is globally valid. To assert that something is global, then, is to make a claim that it is valid for all people everywhere (cf. Walker, 20I5). It differs from universalism in restricting its claim to the present, namely to claim something is global is not to declare it to be a truth for all time. Rather, to claim something as global is to posit the existence of a norm or standard with global geographical extension. The consequence of asserting a shared global norm is that it allows people and actors to be judged according to the posited global standard. Global development indicators, ${ }^{5}$ like all global social indicators, thus gain their power by asserting the existence of an ideal for an aspect of social life that is claimed to be shared globally. This claim to globality is often implicit - as in the Doing Business indicators or the HDI - and tends to be more explicit where indicators are based openly on human rights standards - such as Freedom House's 'Freedom in the World' ranking.

Drawing on existing analysis of a range of development indicators (Merry et al., 2015; Rottenburg et al., 20I5; Cooley and Snyder, 20I5), as well as my own analysis, it seems to me that the assertion of global validity in development indicators is based on three main foundations: human well-being, human behaviour and assertions of shared concepts such as freedom of speech or corruption. I am not suggesting that these are the only foundations for asserting global validity; nor that the three bases operate separately, namely that the Doing Business indicators concern human behaviour and the HDI is built solely upon shared notions of well-being. All three are present to varying degrees in all of the global development indicators considered here, which is not to say that they are present in all development indicators.

The belief in a globally shared notion of human well-being is what underpins, for example, the various types of poverty indicators. If we take the HDI, produced by the UNDP, it is a composite statistic designed to measure health, education and standard of living. Health is measured by life expectancy at birth; the mean of years of schooling for adults aged twenty-five years and older, together with the expected years of schooling for children entering education measures education; and the standard of living is measured by gross national income per capita. These three indicators are then used to rank countries into four tiers of human development.

The UNDP is explicit that its indicators simplify human development and capture only part of what development entails. ${ }^{6}$ This is an admirable piece of self-criticism. Moreover, there is a simple

5 The exception is economic indicators. Whilst they ultimately assert a shared metric based upon what constitutes economic life, and the economy can arguably not be separated from the society in which it is situated, they are not really the target of this critique. They remain subject of course to the accuracy and complexity critiques. 
beauty to the HDI. Yet, by homing in on these three criteria for human development, the HDI is asserting that these three criteria - health, education and standard of living as measured by income - are the most important in measuring human development. The implicit claim is not that these three criteria capture all of human development or human well-being, but that they are a globally shared proxy for it. Put differently, the claim underpinning the global validity of the HDI is that enough people on the planet would - if asked - rank health, education and income as the three most important aspects of their well-being. While this may seem intuitive, there is no empirical evidence to suggest that this is the case. It may be that a particular community would instead place access to land as essential to their well-being, to what a good life means to them; or that women would place personal security above health. Similarly, a culture or community might value living a worthy life - however that is determined - above living a long life; that what is valuable is not how long one is on the planet, but how one lives when one is here (e.g. Lear, 2008). ${ }^{7}$

Of course, it could be argued, for example, that standard of living as measured by income is a proxy for land. But the importance of access to land is often more than simply the income that can be derived from it; there can be a spiritual relationship to land, particularly when ancestors are buried on it. In interviews amongst Batwa communities in Rwanda, for example, access to land comes up regularly as key to a good life; yet land here represents not only steady access to food and possible additional income from selling surplus product, but also denotes membership in the broader community. Having land is akin to having status in the eyes of the non-Batwa majority (at least as our interviewees perceive it). ${ }^{8}$ For this community, standard of living is not a suitable stand-in for access to land. Likewise, life expectancy for the Crow Nation could not substitute for the quality of a life as measured by honour (Lear, 2008).

A second level claim made by the choice of indicators in the HDI concerns the best way of measuring the selected criteria, such as by taking life expectancy at birth as the best measure of health. This criterion was almost certainly chosen because of the difficulty of finding a crossculture measure of health and because there are likely to be good data on it. However, even in the West, as a result of ageing populations, we are beginning to question whether health is in fact better measured as quality rather than quantity. Where we would anticipate that individuals have reason to value their health and the health of those dear to them - and could thus view health as a global good - what good health means and the degree of importance it is given in relation to other goods (i.e. how it is ranked or prioritised) differs across communities.

The second basis - following on from the above notion of value pluralism - I wish to draw out about assumptions concerning the global validity of development indicators is the belief that human behaviour can be measured according to a shared metric; that is, we all behave in very similar ways despite our differing social and cultural contexts. An example of such assumptions at work in development indicators is the World Bank's Doing Business Indicators (DBI). The DBI measures the extent of a state's business-friendliness, thereby assuming that how businesses operate, namely how entrepreneurs and managers understand the function of business in the multiple contexts

7 The cultural devastation the Crow Nation experienced in the course of the twentieth century was caused by the substitution of the material attributes of development - including a longer life - for the standards that defined achievement in their terms.

8 The interviews referred to are part of a Dutch Science Foundation (NWO-WOTRO) project examining the structural barriers of Batwa to participation in society. Under this project, we have conducted $\mathrm{I} 2 \mathrm{O}$ semistructured six- to eight-hour interviews of Batwa individuals in Rwanda in 2015 and 2016 with the goal of ascertaining, in part, what the good life means for this community. To this end, they were explicitly asked to rank the three most important elements of a good life. The top three in our provisional findings are land, education and housing. The project findings have yet to be published; however, the data are on file with the author and can be accessed on request. See <http://www.nwo.nl/en/research-and-results/researchprojects/i/46/I I 946.html (accessed Io October 20I7). 
within which businesses operate and how they conduct themselves in their daily work life can be measured against a globally valid standard (for helpful critiques of the DBI, see Davis and Kruse, 2007; Perry-Kessaris, 2003; Hallward-Driemeier and Pritchett, 2015).

However, recent research into how start-up entrepreneurs in the mobile-phone-application sector in Kenya, Ghana and Zambia think about their businesses suggests that they are generally uninterested in the formalisation of their business and pay little attention to intellectual property rights, which in Kenya at least are now automatically accorded them under new TRIPS-compliant national legislation (Weijers, 20I4). This study by Hanna Weijers, based upon twelve months of fieldwork amongst mobile-phone start-ups, suggests that it is not the costs of formalisation that put these entrepreneurs off registering their businesses - as the DBI assume - but a different way of thinking about a business. In the countries and sector studied, while proud of their work, entrepreneurs appeared to have both a different attitude to the notion of property and, instead, viewed their start-ups as something not indistinct from themselves and the community in which they were situated. What is important in stimulating start-ups, her study suggests, is not better rules to protect business owners, but a greater availability of start-up capital; laws on contract or intellectual property (IP) enforcement made very little difference to how these entrepreneurs behaved. While limited to the sector and countries studied, this research suggests that entrepreneurs do not behave in the same way everywhere because they do not value the same things in the same way. The entrepreneurs studied by Weijers valued their business and being successful but understood success in a different way; moreover, they understood their relationship to those around them, including their customers, in a different way to that assumed by the DBI.

This assumption of the possibility of a shared metric for human behaviour is also made in the personal and family contexts. While all human beings are capable of experiencing suffering, how we experience or respond to that suffering will be culturally and socially determined. A I999 World Bank study examining how the poor understand their own poverty across forty-seven countries found similarities in how the poor conceptualise what it is to be poor (a lack of assets) and in the types of suffering that poverty causes (physical, emotional, psychological) (Narayan et al., I999). However, what the study also shows is that there are significant differences in what priority the poor give to the different indignities and sufferings of poverty. In addition, the study also finds differences in how the interviewees respond to severe poverty, namely how it conditions or affects their behaviour. The poor in different countries not only did not feel poverty in the same way; they also did not prioritise different aspects of well-being in the same way. Moreover, they did not respond in the same way to their poverty. When faced with a lack of stable access to assets, the head of a family in one setting might decide to prioritise investment in social capital over the health and well-being of a child; for example, a cow that can be sold to pay for medicine can also be slaughtered as part of a contribution to a village celebration (Narayan et al., I999). Socio-economic realities condition such a desperate choice, but so do the norms that govern how membership in a community functions.

Similarly, how we react to a change in circumstances will also differ from context to context. An on-going study of the impact of electrification on gender empowerment in the Global South, led by a team at the University of Oslo, has found significant differences in how the arrival of electricity impacts upon the standing of women in a community. The idea that electrification is likely to empower women as the living standards of a community improve is not proving to be a uniform response: whether electrification gave women greater power over their own lives - by for example saving them time on daily chores or by enabling them to start businesses - depended, the study finds, almost entirely on the social context (Winther, 2016). ${ }^{9}$

9 See the project website for more information: 〈http://www.efewee.org/index.php〉 (accessed ro October 2017). 
The third basis for claims concerning a shared global metric of development is the most obvious and the most obviously flawed: the assumption that concepts, such as corruption or empowerment, are themselves globally valid (Kerry-Pessaris, 20II). In the electrification study above, how empowerment was envisaged by the women in the communities studied differed markedly: in the community studied in Kenya, empowerment was viewed as material improvement; in India, it was political, understood as genuine participation in decision-making within the community. Similarly, the lack of shared agreement on the meaning of corruption has led Tara Polzer to adroitly note that corruption is simply a term for something that we do not like (Polzer, 200I). The assumption that we all value a corruption-free environment in the same way denies the very obvious sociocultural determinants of what corruption is and the impact that it has upon individuals and communities, namely why they have reasons to care about it and hence to label it as corruption. Thus, whilst we may perhaps be able to achieve broad global agreement on a handful of core concepts - such as the pre-9/I I agreement on the prohibition on torture or the importance of the rule of law - we cannot agree on what torture consists of, let alone the rule of law. Any agreement is predicated on the vagueness of the concept's content. This might work for the creation of lists of human rights, but it does not allow the creation of a metric for measuring a concept. Global metrics require global agreement on the content of a concept - on what is to be measured - and it is precisely this that is lacking.

It may be suggested that I am proposing a radical cultural relativism that sees nothing of human life as shared. This is not the case; human experience is not infinite. Instead, I think that it is possible to put forward a core group of capabilities that sufficiently capture the essence of a good life for the vast majority of people on the planet today (Nussbaum, 20II; Wolff and de-Shalit, 2007; Alkire, 2002). ${ }^{\text {Io }}$ However, while it may be possible to identify a list of capabilities or elements of a good life that are more or less shared, crucially, how we give those elements content and the relative weighting that we give to them in constructing our notion of what makes a life valuable are likely to differ, often quite radically. ${ }^{\text {II }}$ These differences may be driven by socio-economic disparities across communities or states. Or they may be driven by culture; or by different individual priorities. One of the surprising findings of the research project into conceptions of the Batwan good life has been the response to the capability of 'being able to live with concern for and in relation to animals, plants, and the world of nature' (Nussbaum, 20II, p. 36). Despite being traditional forest-dwellers and being identified outside the community as an indigenous people, this is the category that our research shows is of least interest to the current community. That human beings have some relationship with 'nature' can perhaps be assumed; but what that relationship precisely is, the form that it takes and the priority given to it in relation to other goods or functionings cannot be defined. If this is the case, it is impossible to construct a shared metric for the human experience in general or elements of human well-being or behaviour or values that are cross-culturally relevant and hence global.

That this is the conclusion should not come as a surprise. The claim that there are globally valid sets of norms that the Global South needs to adopt in order to develop is rejected not only by wishywashy lefties and self-styled critics. It is also rejected by development economists, including the World Bank. Writing in the preface to the World Bank report, Economic Growth in the Iggos:

Io In our project with the Batwa, we started with the list of capabilities put forward by Nussbaum. The list was amended and augmented following extensive discussions with members of the community, researchers and practitioners with experience of working in the community; the list was further amended after a pilot study of twenty interviews.

I I I am not suggesting that how we understand a good life is unchanging or immune to influence from outside. The emphasis, for example, given to access to agricultural land by Batwa communities is not a part of their traditional way of life, given that, until relatively recently, Batwa were known as forest-dwellers. See Ndahinda (20II). 
Learning from a Decade of Reform, Gobind Nankani, the then vice-president of the World Bank, states that 'there is no unique universal set of rules.... [W]e need to get away from formulae and the search for elusive "best practices"' (2005, p. xiii). The development industry has by and large accepted in recent years that there is 'no one-size-fits-all' policy solution. As Banerjee has lamented of his field of development economics:

'the only theories that we hold onto with some confidence are disaster warnings - banning all trade is bad, as is banning all private enterprise and printing money to pay everyone. With anything more nuanced, or less negative, there are too many doubts and differences.' (Banerjee, 2007, p. I37; also Szirmai, 2008)

He draws from this the conclusion that cross-country data are not up to the task of telling us what works in development - that is, in alleviating poverty or improving economic growth or in enhancing freedom. And the reason for this is that context is all.

It is this acknowledgement that general policy prescriptions - such as school vouchers or computer kiosks in rural areas - for achieving goals such as improvement in educational outcomes or levels of entrepreneurialism have not made a difference that has driven the rise of randomised trials within development economics. Adopted from the medical field, randomised trials attempt to measure whether interventions work by eliminating the many variables. In order to know, for example, whether providing flip charts to primary schools helps to improve educational attainment, we need to compare schools situated in communities with similar socioeconomic levels, with teachers with similar levels of higher education and attendance, and so on. By providing flip charts to one of these schools and not to the other, and then by monitoring the pupils' achievements over a period of time, we will know whether investing in flip charts is a good idea, or whether the money would be better spent on something else, such as de-worming tablets. However, while a randomised trial might provide strong evidence for recommending investment (or not) in flip charts in the type of community in which the trial is conducted in, say, Malawi, it will not tell us whether flip charts are a good idea elsewhere, in a different setting, in a different country. Ricardo Hausmann, former Chief Economist of the Inter-America Development Bank, has made precisely this point in a recent paper. He notes that lessons do not travel well: while a randomised controlled trial may show that giving children micro-nutrients increases their educational performance in Guatemala, there is no reason to suspect that it would do the same with children in Vietnam (Hausmann, 2016). Put differently, the external validity of randomised trials outside highly controlled environments is doubtful - that is, the trials are not generalisable. Putting to one side the debate within development economists about whether randomised trials are the only legitimate basis for policy prescriptions, this shift to evidence-based learning familiar to anyone within the development world - takes its lead from the recognition that generalised, cross-country policy prescriptions do not work (Rodrik, 2008). They do not work because of the very many different social contexts in which such prescriptions are meant to apply.

\section{Legitimacy: the emperor has no clothes}

In their introductory paper, Mathias Siems and David Nelken highlight the importance of focusing on 'indicators in action' (Siems and Nelken, 2017) and go on to provide a plan for thinking about the legitimacy of the practice of global indicators. They conclude that grappling with the legitimacy of global indicators requires us to think about the trade-offs between different types of legitimacy, so that how we assess the legitimacy of one set of indicators will differ from an assessment of another set that purports to measure something else. This sounds very reasonable. However, in relation to global development indicators, I wonder whether such an approach only helps us to 
ignore the naked emperor in the room. If we accept the globality critique, is the legitimacy of global development indicators not fatally undermined, regardless of the nuances that a conception of networked legitimacy provides?

The globality critique suggests that there is no globally shared conception of what it is to be developed; that value pluralism at the most basic level of what we have reason to value gives lie to the claim to global validity. Why does this matter? Either indicators reflect globally agreed standards, and thus premise their legitimacy on the accuracy and representativeness of these standards in their algorithms and data collections; or they impose standards of what the good life is and, where they are successful in gaining recognition, force compliance upon communities for whom those standards may be alien. ${ }^{\mathrm{I2}}$ Both claims - the is and the ought - assume a metric of human well-being that cannot be justified if we are to take the diversity of human experience seriously.

If this is the case, questions about whether a particular indicator is based on objective or subjective data, or created by public or private bodies, or competes in a crowded market-place are irrelevant. Global development indicators are instead naked emperors. This does not mean that some development indicators are not better than others: those that are based on widespread interviews that allow individuals to determine themselves the criteria of measurement, such as what poverty means to them, particularly where interviews are conducted at multiple sites across the planet, are likely to have a greater claim to global validity. But it does suggest that any attempt to root the claim of development indicators to globality must be done at the local level using a reflexive form of methodology.

The globality critique, however, has a deeper bite when we place development indicators in the context of the genealogy of the development discourse more broadly, and it helps us to answer the question - given the widespread scepticism concerning the transferability of development knowledge and thus of the utility of comparative studies - of what purpose global development indicators then serve.

The work of TWAIL scholars ${ }^{\mathrm{I}}$ has shown almost beyond dispute how the development movement of the latter half of the twentieth century within international law has its roots in the colonial encounter between European countries and the non-European other. Their work exposes how the concepts we use to structure and order our world have their origins in this meeting of worlds. It does not require much imagination to see how non-Christian barbarians became the under-developed of the mandate era or the corrupt, fragile states of our own. Deprivation is a relational concept, and our ideas about poverty and about development are intertwined with the geopolitical discourse of which they are part. The idea of development is a crucial foundation stone of contemporary global governance and of the relationship between the Global North and Global South (Pahuja, 20II). The notion of development that arose from this relationship is one that sees the 'developing world' as lacking something that we - the developed world - have (Escobar, I995). This 'thing' that developing countries lack has shifted from the lack of civilisation and statehood under colonialism to, over the decades of the twentieth century, the lack of industrialisation and material goods, education systems and health care, good governance, the rule of law and, most recently, access to justice. The common thread underpinning these shifts has been the belief that what developing countries lack is the ability to achieve these Northernselected markers of civilisation on their own. As such, they require intervention.

At the same time, a second core shift of the post-World War II development movement has been the allocation of responsibility for their under-development to the newly independent states. The

I 2 Uribe makes a similar point.

I3 See, inter alia, Anghie (2005; 2006); Rajagopal (2003); Pahuja (20I I). 
duty identified by Truman in his I946 inaugural address to provide the technology necessary for material progress had, by 1986, been replaced by the Right to Development, which places the duty for delivering development onto the developing state. ${ }^{14}$ The focus on good governance, rule of law, corruption and human rights within the development movement all work to allocate the responsibility for the failure to address poverty squarely to the Global South, absolving the rules of the global order and the states of the Global North from their not insignificant part in creating and sustaining poverty.

Global development indicators are a continuation of this pattern of interventionism - the contemporary twist of the civilising narrative. They reflect and embody the standards of civilisation that developing states must aspire to if they are to join the club of civilised states. By creating standards about what individuals should value and how they should live, and by providing an easy means to judge compliance, development indicators tell us how far developing countries are falling below the standards set for them by the development actors and institutions of the Global North. Moreover, indicators allow us to discipline developing countries for their failure to achieve development, both by emphasising and broadcasting their failure in rankings and by linking failure to development funding. This combination of internal and external disciplining continues the trend for assigning responsibility for failure to the Global South. They also reflect the basis ideology of development that sees development as a problem of the Global South and the solution as coming from the North. It is their value as a means of governing the Global South that arguably explains the incompatibility of the promotion of development indicators at the same time as the same institutions accept the globality critique and recognise the futility of best practice in development.

What does this have to do with how we assess the legitimacy of development indicators? While they may be naked emperors, they remain emperors nonetheless. Although indicators are part of a global trend for accountability (Davis et al., 2012), it matters who is demanding this accountability, who is managing it and to whom the accountability is owed. Power should be accountable but to individuals and communities, not to the World Bank or agencies of donor governments. Global development indicators do not help citizens do that. The globality critique developed here is applicable to states and peoples in the Global North as well as the South; yet, its bite is the role of development indicators in perpetuating the dominance of the Global North within global governance.

This is not to suggest that we abandon data collection or that we give up on attempting to understand the complexity of life in societies other than our own; but rather that what we abandon is the assumption that we know a priori what other communities have reason to value, what development or human well-being means to them. If we accept this, then we cannot accept metrics that assert a globally valid way of capturing the human experience. Instead, we might just have to ask.

\section{References}

ALKIRE, Sabina (2002) Valuing Freedoms: Sen's Capability Approach and Poverty Reduction. Oxford: Oxford University Press.

ANGHIE, Anthony (2005) Imperialism, Sovereignty and the Making of International Law. Cambridge: Cambridge University Press.

I4 Inaugural Address of Harry S. Truman, 20 January I949; available via the digital Truman presidential library at 〈http://www.trumanlibrary.org/whistlestop/50yr_archive/inagural2ojanI949.htm〉 (accessed Io October 2017); I986 Declaration on the Right to Development, GA Res. I28, UN GAOR, 4Ist Sess., Supp. No. 53, UN Doc. A/RES/4I/I28 (I986), I86. 
ANGHIE, Anthony (2006) 'The Evolution of International Law: Colonial and Postcolonial Realities',

Third World Quarterly 27: 739-753.

BANERJEe, Abhijit V. (2007) Making Aid Work. Cambridge, MA: MIT Press.

BASSETT, Thomas J. (I994) 'Cartography and Empire Building in Nineteenth-Century West Africa', Geographical Review 84: 316-335.

COOLEy, Alexander and SNyder, Jack (2015) Ranking the World: Grading States as a Tool of Global Governance. Cambridge: Cambridge University Press.

Davis, Kevin E. and Kruse, Michael B. (2007) 'Taking the Measure of Law: The Case of the Doing

Business Project', Law and Social Inquiry 32: I095-I I 9.

DAVIS, Kevin E., KINGSBURY, Benedict and MERRY, Sally Engle (20I 2) 'Introduction: Global Governance by Indicators' in Kevin Davis, Angelina Fisher, Benedict Kingsbury and Sally Engle Merry (eds)

Governance by Indicators: Global Power through Quantification and Rankings. Oxford: Oxford University Press, 3-28.

escobar, Arturo (1995) Encountering Development: The Making and Unmaking of the Third World. Princeton: Princeton University Press.

ESPELAND, Wendy (2015) 'Narrating Numbers' in Richard Rottenburg, Sally Engle Merry, SungJoon Park and Johanna Mugler (eds) The World of Indicators: The Making of Governmental Knowledge through Quantification. Cambridge: Cambridge University Press, 56-75.

Gallie, W.B. (I956) 'Essentially Contested Concepts', Proceedings of the Aristotelian Society 56: I67-I98. GERRETS, Rene (2015) 'Charting the Road to Eradication: Health Facility Data and Malaria Indicator Generation in Rural Tanzania' in Richard Rottenburg, Sally Engle Merry, Sung-Joon Park and Johanna Mugler (eds) The World of Indicators: The Making of Governmental Knowledge through Quantification. Cambridge: Cambridge University Press, I5I-I87.

HALLWARD-DRIEMEIER, Mary and PRITCHETt, Lant (20I5) 'How Business Is Done in the Developing World: Deals versus Rules', Journal of Economic Perspectives 29: I 2 I-I 40.

Hausmann, Ricardo (20I6) 'The Problem with Evidence-Based Policies’, 25 February 20r6. Available at: https:/www.project-syndicate.org/commentary/evidence-based-policy-problems-by-ricardo-haus mann-2016-02?barrier=accessreg (accessed I8 October 2017).

Jerven, Morten (2013) Poor Numbers: How We Are Misled by African Development Statistics and What To Do About It. Ithaca, NY: Cornell University Press.

LEAR, Jonathan (2008) Radical Hope: Ethics in the Face of Cultural Devastation. Cambridge, MA: Harvard University Press.

MERRY, Sally Engle, DAvis, Kevin E. and KInGSBURY, Benedict (eds) (20I5) The Quiet Power of Indicators: Measuring Governance, Corruption and the Rule of Law. Cambridge: Cambridge University Press. Michell, Joel (2005) 'The Logic of Measurement: A Realist Overview', Measurement 38: 285-294. NANKANI, Gobind (2005) Economic Growth in the I 990 : Learning from a Decade of Reform. Washington: The World Bank.

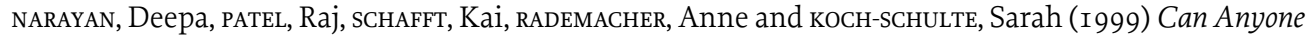
Hear Us? Voices from 47 Countries. Washington: World Bank.

NDAHINDA, Felix Mukwiza (20I I) Indigenousness in Africa: A Contested Framework for Empowerment of 'Marginalized' Ethno-Cultural Communities. Den Haag: T.M.C. Asser Press.

nussbaum, Martha C. (20I I) Creating Capabilities: The Human Development Approach. Cambridge, MA: Belknap Press.

PAHUJA, Sundhya (20I I) Decolonising International Law. Cambridge: Cambridge University Press. PERRY-KESSARIS, Amanda (2003) 'Finding and Facing Facts about Legal Systems and Foreign Direct Investment in South Asia', Legal Studies 23: 649-689.

PERRY-KESSARIS, Amanda (20 I I) 'Prepare Your Indicators: Economics Imperialism on the Shores of Law and Development', Journal of International Law in Context 7: 40I-42 I. 
POGGE, Thomas and wIsOR, Scott (20I6) 'Measuring Poverty: A Proposal' in Matthew Adler and Marc Fleurbaey (eds) Oxford Handbook of Well-Being and Public Policy. Oxford: Oxford University Press, 645-676.

POLZER, Thomas (200I) Corruption: Deconstructing the World Bank Discourse. LSE Destin Working Paper

No. OI-I8 (200I). Available at: 〈http://www.lse.ac.uk/internationalDevelopment/pdf/WP/WPI8.

pdf $>$ (accessed Io October 2017).

RAJAGOPAL, Balakrishnan (2003) International Law from Below: Development, Social Movements and Third

World Resistance. Cambridge: Cambridge University Press.

REDdy, Sanjay G. and Pogge, Tomas (2010) 'How Not to Count the Poor' in Sudhir Anand, Paul Segal and Joseph Stiglitz (eds) Debates in the Measurement of Poverty. Oxford: Oxford University Press.

RODRIK, Dani (2008) The New Development Economics: We Shall Experiment, but How Shall We Learn?

October, Harvard Kennedy School Faculty Research Working Paper Series, RWPo8-055.

Available at: 〈https://ssrn.com/abstract=I296II5〉 (accessed Io October 2017).

ROTTENBURG, Richard, MERRY, Sally Engle, PARK, Sung-Joon and MUGLer, Johanna (eds) (2015) The World of

Indicators: The Making of Governmental Knowledge through Quantification. Cambridge: Cambridge

University Press.

SERBAn, Mihaela (2015) 'Rule of Law Indicators as a Technology of Power in Romania' in Sally

Engle Merry, Keven E. Davis and Benedict Kingsbury (eds) The Quiet Power of Indicators: Measuring Governance, Corruption and Rule of Law. Cambridge: Cambridge University Press, I99$22 \mathrm{I}$.

SIEMS, Mathias and NELKEn, Delken (2017) ‘Global Social Indicators and the Concept of Legitimacy’ (in this issue).

SzIRMAI, Adam (2008) Explaining Success and Failure in Development. UNU-Merit Working Paper 2008-

or3. Available at: 〈http://www.merit.unu.edu/publications/working-papers/abstract/?id=3032〉 (accessed io October 2017).

URIBE, María Angélica Prada (2015) 'The Quest for Measuring Development: The Role of the Indicator

Bank' in Sally Engle Merry, Keven E. Davis and Benedict Kingsbury (eds) The Quiet Power of

Indicators: Measuring Governance, Corruption and Rule of Law. Cambridge: Cambridge University

Press, I33-I55.

WALKER, N. (20I5) Intimations of Global Law. Cambridge: Cambridge University Press.

weIJERs, Hanna (2014) Made in Africa: A Discussion on the Role of Law in Absorptive Capacity in African Software Industries. Oisterwijk: Wolf Legal Publishers.

Winther, Tanja (2016) 'Women’s Empowerment in Energy Projects: What Is the Meaning?', paper delivered at the Symposium Engendering the Energy Transition: Theory meets policy and practice, South meets North, University of Twente, The Netherlands, 23-24 November 2016 (on file with the author).

wolfF, Jonathan and DE-Shalit, Avner (2007) Disadvantage. Oxford: Oxford University Press. 